\title{
BENTUK PERLINDUNGAN DAN JAMINAN HAK PEKERJA/BURUH OUTSOURCING PADA PUTUSAN MAHKAMAH KONSTITUSI NOMOR 27/PUU-IX/2011
}

\author{
Oleh : \\ Mashudi**, Zulfiqar Bhisma Putra Rozi**, Sugeng Paryitno* \\ *Mahasiswa Fakultas Hukum Program Pascasarjana Universitas Sunan Giri Surabaya, \\ Email : regangerrach@gmail.com \\ **Dosen Fakultas Hukum Universitas Gresik \\ Email: Mashudiunigres@gmail.com / Zulfiqar.putra007@gmail.com
}

\begin{abstract}
ABSTRAK
Keberadaan perusahaan penyedia jasa tenaga kerja atau dalam istilah lain disebut outsourcing bagi sebagian orang dinilai seperti perbudakan gaya modern. Dinilai demikian karena perusahaan tersebut seolah-olah memperdagangkan tenaga kerja sebagai pemenuhan terhadap kebutuhan pelaku usaha. Namun bagi sebagian orang lainnya pendapat demikian tak sepenuhnya benar. Perlindungan pekerja/buruh outsourcing diatur dalam Pasal 65 dan Pasal 66 Undang-Undang Nomor 13 Tahun 2003 Tentang Ketenagakerjaan. Namun setelah adanya uji materi pada putusan Mahkamah Konstitusi Nomor 27/PUU-IX/2011 menganulir ketentuan dalam Pasal 65 ayat (7) dan Pasal 66 ayat (2) huruf b Undang-Undang Nomor 13 Tahun 2003 tentang Ketenagakerjaan, sepanjang dalam perjanjian kerja tersebut tidak disyaratkan adanya pengalihan perlindungan hak-hak bagi pekerja/buruh yang objek kerjanya tetap ada, walaupun terjadi pergantian perusahaan yang melaksanakan sebagian pekerjaan borongan dari perusahaan lain atau perusahaan penyedia jasa pekerja/buruh.
\end{abstract}

Kata kunci : Outsourcing, Perlindungan, Penyedia jasa

\begin{abstract}
The existence of a labor service provider company or in other terms is called outsourcing for some people is considered as a modern style slavery. It is considered so because the company seems to trade in labor as a fulfillment of the needs of business actors. But for some others this opinion is not entirely correct. The protection of outsourced workers / laborers is regulated in Article 65 and Article 66 of Law Number 13 of 2003 concerning Manpower. However, after a judicial review in the decision of the Constitutional Court Number 27 / PUU-IX / 2011 annulled the provisions in Article 65 paragraph (7) and in Article 66 paragraph (2) letter b Law Number 13 of 2003 concerning Manpower, contradicts the 1945 Constitution as long as the employment agreement does not require the transfer of the protection of the rights of workers whose work remains, despite the change of companies that carry out part of the work of other companies or company providing workers / labor services.
\end{abstract}

Keywords $\quad$ : Outsourcing, Protection, Service providers 


\subsection{PENDAHULUAN}

Sebagai bentuk upaya dalam pembangunan nasional yang dilaksanakan dalam rangka pembangunan manusia Indonesia seutuhnya dan pembangunan masyarakat Indonesia seluruhnya serta untuk mewujudkan masyarakat yang sejahtera, adil, makmur, yang merata, baik materiil maupun spiritual berdasarkan Pancasila dan Undang-Undang Dasar Negara Republik Indonesia Tahun 1945 dibentuklah Undang-Undang Nomor 13 Tahun 2003 Tentang Ketenagakerjaan. Undang-undang tersebut diharapkan mampu untuk meningkatkan kualitas tenaga kerja dan peran sertanya dalam pembangunan serta peningkatan perlindungan tenaga kerja dan keluarganya sesuai dengan harkat dan martabat kemanusiaan.

Selain diharapkan mampu untuk meningkatkan kualitas dan kesejahteraan tenaga kerja, kebijakan yang tepat juga harus mampu mendorong laju pertumbuhan ekonomi. Hadirnya perusahaan di tengahtengah masyarakat tentu memainkan peran penting dalam sistem ekonomi di Indonesia. Dalam menghadapi tantangan di era globalisasi saat ini, tenaga kerja merupakan faktor penting bagi perusahaan untuk mencapai tujuan perusahaan tersebut. Manajemen perusahaan dituntut harus bisa mengoptimalkan peranan tenaga kerja yang dimiliki sehingga menghasilkan kinerja yang optimal.

Salah satu strategi untuk memaksimalkan keuntungan perusahaan, penekanan biaya atau efisiensi dalam beroperasi harus dilakukan. Biaya untuk tenaga kerja seringkali menempati urutan tertinggi pengeluaran perusahaan, khususnya pada perusahaan yang berbasis tenaga kerja atau padat karya ditambah lagi seiring naiknya nilai upah tiap tahunnya.
Strategi yang sering dilakukan oleh perusahaan dalam menekan biaya tenaga kerja adalah dengan menggunakan tenaga kerja kontrak baik melalui kontrak oleh perusahaan maupun dengan pelaksanaan pekerjaan kepada perusahaan lainnya. Bentuk pelaksanaannya dapat dilaksanakan melalui perjanjian pemborongan pekerjaan maupun dengan penyediaan jasa tenaga kerja yang dibuat secara tertulis.

Keberadaan perusahaan penyedia jasa tenaga kerja atau dalam istilah lain disebut outsourcing bagi sebagian orang dinilai seperti perbudakan gaya modern. Dinilai demikian karena perusahaan tersebut seolah-olah memperdagangkan tenaga kerja sebagai pemenuhan terhadap pelaku usaha. Namun bagi sebagian orang lainnya pendapat demikian tak sepenuhnya benar. Disisi lain ada pihak yang menyambut baik model penyerahan sebagian pekerjaan kepada perusahaan lain yang memang telah memahami arti penting outsourcing yang telah menjadi kebutuhan manajemen perusahaan dalam konteks efisiensi pekerjaan.

Dalam perkembangannya UndangUndang Nomor 13 Tahun 2003 Tentang Ketenagakerjaan telah mengalami berbagai macam uji materi di Mahkamah Konstitusi. Salah satu putusan Mahkamah Konstitusi terhadap Undang-Undang Nomor 13 Tahun 2003 Tentang Ketenagakerjaan adalah putusan Mahkamah Konstitusi Nomor 27/PUU-IX/2011. Putusan Mahkamah Konstitusi Nomor 27/PPU-IX/2011 merupakan pengalihan tindakan perlindungan bagi Pekerja/Buruh outsourcing sehingga terpenuhinya seluruh hak - hak pekerja/ buruh outsourcing di Indonesia.

Sebagai bentuk pelaksanaan outsourcing yang diarahkan untuk menciptakan iklim hubungan industrial 
yang harmonis, dinamis dan berkeadilan, Pemerintah menerbitkan Peraturan Menteri Ketenagakerjaan dan Transmigrasi Nomor 19 Tahun 2012 tentang Syarat -Syarat penyerahan sebagai pelaksanaan pekerjaan kepada perusahaan lain yang memuat aturan persyaratan, perjanjian, dan pengawasan outsourcing. Bentuk pengalihan sebagian pekerjaan merupakan model baru dalam sistem ketenagakerjaan di Indonesia. Untuk itu dengan hal yang baru ini kiranya hak-hak terhadap Pekerja/Buruh harus tetap diutamakan sesuai dengan tujuan Ketenagakerjaan.

Apabila kita tarik garis besar bagi yang setuju dengan penerapan bentuk sistem kerja outsourcing berdalih bahwa outsourcing bermanfaat dalam pengembangan usaha, memacu tumbuhnya bentuk-bentuk usaha baru (kontraktor) yang secara tidak langsung membuka lapangan pekerjaan bagi para pencari kerja, dan bahkan di berbagai negara praktik seperti ini bermanfaat dalam hal peningkatan pajak, pertumbuhan dunia usaha, pengentasan pengangguran dan kemiskinan serta meningkatkan daya beli masyarakat, sedangkan bagi perusahaan sudah pasti, karena setiap kebijakan bisnis tetap berorientasi pada efisiensi biaya dan keuntungan. Disisi lain muncul kerugian yang ditimbulkan misalnya, upah pekerja/buruh menjadi lebih rendah, tidak ada jaminan sosial, meskipun ada jaminan sosial tersebut hanya sebatas minimal, tidak adanya perlindungan pekerjaan (job security) serta tidak adanya jaminan pengembangan karier.

\subsection{KAJIAN TEORI}

Secara umum dalam UndangUndang Nomor 13 Tahun 2003 Tentang Ketenagakerjaan, pekerja/buruh adalah setiap orang yang bekerja dengan menerima upah atau imbalan dalam bentuk lain. Selain pekerja/buruh dalam hubungan kerja juga ada pemberi kerja yang dalam Undang-Undang Nomor 13 Tahun 2003 Tentang Ketenagakerjaan, Pemberi kerja adalah orang perseorangan, pengusaha, badan hukum, atau badan-badan lainnya yang mempekerjakan tenaga kerja dengan membayar upah atau imbalan dalam bentuk lain. Pada umumnya upah atau imbalan dalam bentuk lain yang diberikan adalah dalam bentuk uang sehingga mudah dan efektif dalam penghitungannya.

Outsourcing dalam Bahasa Indonesia diterjemahkan sebagai "alih daya". Dalam praktik, pengertian dasar outsourcing adalah pengalihan sebagian atau seluruh pekerjaan dan atau wewenang kepada pihak lain guna mendukung strategi pemakai jasa outsourcing baik pribadi, perusahaan, divisi ataupun sebuah unit dalam perusahaan. ${ }^{1}$

Thomas L. Wheelen dan J. David Hunger yang dikutip Amin Widjaja Tunggal, mengartikan: "Outsourcing is a process which resources are purchase from others through ling-term contracts instead of being made with the company (for example,Hewlett Packard buys its laser engines from canon for HP's laser jetprinters), to strategic alliances, in which partnerships. (Outsourcing adalah suatu proses yang mana seluruh barang diadakan dari pihak lain melalui kontrak-kontrak jangka panjang yang dilakukan oleh
1 Komang Priambada \& Agus Eka Maharta, Outsourcing Versus Serikat Pekerja?, Alihdaya Publishing, Jakarta, 2008, h. 12. 
perusahaan (misalnya Packard mengadakan mesin-mesin lasernya dari Canon untuk printer-printer laser Jet) perusahaan Hewlett Packard itu sendiri). ${ }^{2}$

Selanjutnya Mason A. Carpenter dan WM. Gerland Sanders, yang juga dikutip oleh Amin Widjaja Tunggal mengatakan: ${ }^{3}$

1. Outsourcing is activity performed for company by people other than itsfull-time employees (Outsourcing adalah pekerjaan yang dilakukan untuk perusahaan oleh orang-orang yang bukan pekerja fulltime perusahaan itu sendiri).

2. Outsourcing is contracting with external suppliers to perform certain partsof a company's normal value chain of activities. Value chain is totalprimary and support value-adding activities by which a firm produces,distributes, and markets a product. (Outsourcing dilakukan melalui kerja sama dengan supplier-supplier dari luar untuk mengerjakan bagian-bagian tertentu rangkaian-rangkaian pekerjaan-pekerjaan yang biasanya dilakukan perusahaan. Rangkaian pekerjaan adalah keseluruhan pekerjaan utama dan penunjang yang dilakukan perusahaan untuk memproduksi, mendistribusikan, dan memasarkan sebuah produk).

Sedangkan menurut Chandra Suwondo, yang dimaksud dengan outsourcing adalah pendelegasian operasi dan manajemen harian dari suatu proses bisnis kepada pihak luar (perusahaan

2 Amin Widjaja Tunggal, Outsourcing Konsep dan Kasus, HARVINDO, Jakarta, 2008, h. 11.

${ }^{3}$ Ibid. penyediaan jasa outsourcing), melalui pendegelasian, maka pengelolaan tak lagi dilakukan oleh perusahaan jasa outsourcing. ${ }^{4}$

Outsourcing adalah penyerahan pekerjaan tertentu suatu perusahaan kepada pihak ketiga yang dilakukan dengan tujuan untuk membagi risiko dan mengurangi beban perusahaan tersebut. Penyerahan pekerjaan tersebut dilakukan atas dasar perjanjian kerjasama operasional antara perusahaan pemberi kerja (principal) dengan perusahaan penerima pekerjaan (perusahaan outsourcing). Dalam praktik, perusahaan pemberi pekerjaan menetapkan kualifikasi dan syarat-syarat kerja, dan atas dasar itu perusahaan outsourcing (perusahaan penerima pekerjaan) merekrut calon tenaga kerja. Hubungan hukum pekerja bukan dengan perusahaan pemberi pekerjaan tetapi dengan perusahaan penerima pekerjaan. Dalam kaitan ini, ada tiga pihak dalam sistem outsourcing, yaitu perusahaan principal (pemberi pekerjaan), perusahaan jasa outsourcing (penyedia tenaga kerja), dan tenaga kerja. ${ }^{5}$

Pada Undang-Undang Nomor 13 Tahun 2003 Tentang Ketenagakerjaan, kata outsourcing tidak disebutkan secara langsung, namun disebutkan sebagai "menyerahkan sebagian pekerjaan kepada perusahaan lain." Outsourcing sendiri merupakan istilah yang lazim digunakan dalam dunia industri dengan makna yang kurang lebih sama dengan maksud yang diuraikan oleh Nomor 13 Tahun 2003 Tentang Ketenagakerjaan. Penyerahan pekerjaan kepada perusahaan lain atau outsourcing tersebut diatur pada pasal 64,

4 Chandra Suwondo, Outsourcing, Implementasi di Indonesia, Praminta Offset, Jakarta, 2008 , h. 1

5 Libertus Jehani, Hak-hak Karyawan Kontrak, Praminta Offset, Jakarta, 2008, h. 1. 
pasal 65 (terdiri dari 9 ayat) serta pasal 66 (terdiri dari 4 ayat).

Dari pengertian outsourcing sebagaimana tersebut di atas, maka dalam bidang hukum ketenagakerjaan ketentuan yang mengatur outsourcing secara implisit ditentukan dalam Pasal 64 sampai dengan Pasal 66 Undang-Undang Nomor 13 Tahun 2003 Tentang Ketenagakerjaan. Dalam Pasal 64 Undang-Undang Nomor 13 Tahun 2003 Tentang Ketenagakerjaan disebutkan bahwa perusahaan dapat menyerahkan sebagian pelaksanaan pekerjaan kepada perusahaan lainnya melalui perjanjian pemborongan pekerjaan atau penyedia jasa pekerja/buruh yang dibuat secara tertulis.

Ketentuan di dalam Pasal 64 Undang-Undang Nomor 13 Tahun 2003 Tentang Ketenagakerjaan inilah yang sering disebut outsourcing. ${ }^{6}$ Ketentuan outsourcing sebagaimana Pasal 64 UndangUndang Nomor 13 Tahun 2003 Tentang Ketenagakerjaan tersebut di atas bukanlah merupakan sesuatu yang diwajibkan, melainkan ketentuan tersebut lebih merupakan pilihan bebas, karena itu dalam pelaksanaannya pemanfaatan outsourcing diserahkan pada perhitungan untung rugi dari perusahaan.

Kontrak dan outsourcing adalah bentuk hubungan kerja yang termasuk dalam kategori precarious work, istilah yang biasa dipakai secara internasional untuk menunjukkan situasi hubungan kerja yang tidak tetap, waktu tertentu, kerja lepas, tidak terjamin/ tidak aman dan tidak pasti. ${ }^{7}$ Ada beberapa peraturan dari tingkat undang-undang maupun Keputusan Menteri yang mengatur hubungan kerja outsourcing antara lain:

6 Abdul Rachmad Budiono, Hukum Perburuhan, PT Indeks, Jakarta, 2009, h. 42.
1. Pasal 1601b Kitab Undang-Undang Hukum Perdata;

Pemborongan pekerjaan adalah persetujuan, dengan mana pihak yang satu, si pemborong, mengikatkan diri untuk menyelenggarakan suatu pekerjaan bagi pihak yang lain, pihak yang memborongkan, dengan menerima suatu harga yang ditentukan.

2. Pasal 64 sampai dengan Pasal 66 Undang-Undang Nomor 13 Tahun 2003 Tentang Ketenagakerjaan;

Pasal 64

Perusahaan dapat menyerahkan sebagian pelaksanaan pekerjaan kepada perusahaan lainnya melalui perjanjian pemborongan pekerjaan atau penyediaan jasa pekerja/buruh yang dibuat secara tertulis

Pasal 65

(1) Penyerahan sebagian pelaksanaan pekerjaan kepada perusahaan lain dilaksanakan melalui perjanjian pemborongan pekerjaan yang dibuat secara tertulis.

(2) Pekerjaan yang dapat diserahkan kepada perusahaan lain sebagaimana dimaksud dalam ayat (1) harus memenuhi syarat-syarat sebagai berikut:

a. dilakukan secara terpisah dari kegiatan utama;

b. dilakukan dengan perintah langsung atau tidak langsung dari pemberi pekerjaan;

\footnotetext{
${ }^{7}$ Rina Herawati, Kontrak dan Outsourcing Harus Makin Diwaspadai, Yayasan AKATIGA, Bandung, 2010, h. 1.
} 
c. merupakan kegiatan penunjang perusahaan secara keseluruhan; dan

d. tidak menghambat proses produksi secara langsung.

(3) Perusahaan lain sebagaimana dimaksud dalam ayat (1) harus berbentuk badan hukum.

(4) Perlindungan kerja dan syarat-syarat kerja bagi pekerja/buruh pada perusahaan lain sebagaimana dimaksud dalam ayat (2) sekurangkurangnya sama dengan perlindungan kerja dan syarat-syarat kerja pada perusahaan pemberi pekerjaan atau sesuai dengan peraturan perundang-undangan yang berlaku.

(5) Perubahan dan/atau penambahan syaratsyaratsebagaimana dimaksud dalam ayat (2) diatur lebih lanjut dengan Keputusan Menteri.

(6) Hubungan kerja dalam pelaksanaan pekerjaan sebagaimana dimaksud dalam ayat (1) diatur dalam perjanjian kerja secara tertulis antara perusahaan lain dan pekerja/buruh yang dipekerjakannya.

(7) Hubungan kerja sebagaimana dimaksud dalam ayat (6) dapat didasarkan atas perjanjian kerja waktu tidak tertentu atau perjanjian kerja waktu tertentu apabila memenuhi persyaratan sebagaimana dimaksud dalam Pasal 59.

(8) Dalam hal ketentuan sebagaimana dimaksud dalam ayat (2), dan ayat
(3), tidak terpenuhi, maka demi hukum status hubungan kerja pekerja/buruh dengan perusahaan penerima pemborongan beralih menjadi hubungan kerja pekerja/buruh dengan perusahaan pemberi pekerjaan.

(9) Dalam hal hubungan kerja beralih ke perusahaan pemberi pekerjaan sebagaimana dimaksud dalam ayat (8), maka hubungan kerja pekerja/buruh dengan pemberi pekerjaan sesuai dengan hubungan kerja sebagaimana dimaksud dalam ayat (7)

Pasal 66

(1) Pekerja/buruh dari perusahaan penyedia jasapekerja/buruh tidak boleh digunakan oleh pemberi kerja untuk melaksanakan kegiatan pokok atau kegiatan yang berhubungan langsung dengan proses produksi, kecuali untuk kegiatan jasa penunjang atau kegiatan yang tidak berhubungan langsung dengan proses produksi.

(2) Penyedia jasa pekerja/buruh untuk kegiatan jasa penunjang atau kegiatan yang tidak berhubungan langsung dengan proses produksi harus memenuhi syarat sebagai berikut:

a. adanya hubungan kerja antara pekerja/buruh dan perusahaan penyedia jasa pekerja/buruh; 
b. perjanjian kerja yang berlaku dalam hubungan kerja sebagaimana dimaksud pada huruf a adalah perjanjian kerja untuk waktu tertentu yang memenuhi persyaratan sebagaimana dimaksud dalam Pasal 59 dan/atau perjanjian kerja waktu tidak tertentu yang dibuat secara tertulis dan ditandatangani oleh kedua belah pihak;

c. perlindungan upah dan kesejahteraan, syaratsyarat kerja, serta perselisihan yang timbul menjadi tanggung jawab perusahaan penyedia jasa pekerja/buruh; dan

d. perjanjian antara perusahaan pengguna jasa pekerja/buruh dan perusahaan lain yang bertindak sebagai perusahaan penyedia jasa pekerja/buruh dibuat secara tertulis dan wajib memuat pasal-pasal sebagaimana dimaksud dalam undang-undang ini.

(3) Penyedia jasa pekerja/buruh merupakan bentuk usaha yang berbadan hukum dan memiliki izin dari instansi yang bertanggung jawab di bidang ketenagakerjaan.

(4) Dalam hal ketentuan sebagaimana dimaksud dalam ayat (1), ayat (2) huruf $a$, huruf $b$, dan huruf d serta ayat (3) tidak terpenuhi, maka demi hukum status hubungan kerja antara pekerja/buruh dan perusahaan penyedia jasa pekerja/buruh beralih menjadi hubungan kerja antara pekerja/buruh dan perusahaan pemberi pekerjaan.

3. Keputusan Menteri Tenaga Kerja Nomor KEP.220/MEN/X/2004 Tentang Syarat-Syarat Penyerahan Sebagian Pelaksanaan Pekerjaan Kepada Perusahaan Lain.

4. Keputusan Menteri Tenaga Kerja dan Transmigrasi Nomor KEP.101/MEN/VI/2004 Tentang Tata Cara Perizinan Perusahaan Penyedia Jasa Pekerja/Buruh.

5. Peraturan Menteri Tenaga Kerja dan Transmigrasi Nomor 19 Tahun 2012 tentang Syarat-Syarat Penyerahan Sebagian Pelaksanaan Pekerjaan Kepada perusahaan Lain; Akhirnya melalui Undang-Undang Nomor 13 Tahun 2003 Tentang Ketenagakerjaan, outsourcing diperkenalkan sebagia penyerahan sebagian pelaksanaan pekerjaan kepada perusahaan lainnya melalui perjanjian pemborongan pekerjaan atau penyedia jasa pekerja/buruh. Sehingga dalam outsourcing meliputi penyerahan sebagian pelaksanaan pekerja oleh suatu perusahaan dengan perjanjian pemborongan kepada perusahaan pemborong atau penyerahan sebagian pelaksanaan pekerjaan oleh suatu perusahaan dengan perjanjian penyedia jasa pekerja kepada perusahaan penyedia jasa pekerja/buruh.

Penyerahan atau pelimpahan sebagian pekerjaan kepada perusahaan outsourcing, terlebih dahulu diawali dengan negosiasi antara perusahaan pengguna pekerja outsourcing (perusahaan pemberi pekerjaan) dengan perusahaan outsourcing (perusahaan penerima 
pekerjaan) hingga tercapainya kesepakatan antara kedua belah pihak yang kemudian dituangkan dalam suatu perikatan atau perjanjian, yang dibuat dan ditandatangani oleh kedua belah pihak yang mencantumkan bagaimana prosedur kerjanya, pelaksanaannya, dan kemungkinan yang akan terjadi atau timbul perselisihan dalam praktik outsourcing tersebut. Dalam hal ini sudah tentu termasuk pekerja/buruh.

\subsection{METODE PENELITIAN}

Tipe penelitian ini adalah penelitian hukum normatif. Penelitian hukum normatif adalah penelitian hukum yang meletakkan hukum hukum sebagai sebuah bangunan sistem norma. Sistem norma yang dimaksud adalah mengenai asas-asas, norma, kaidah dari peraturan perundangan, putusan pengadilan, perjanjian serta doktrin (ajaran). ${ }^{8}$

Dalam penelitian ini Penulis akan mengkaji pengaturan Undang-Undang Nomor 13 tahun 2003 tentang Ketenagakerjaan dan Putusan Mahkamah Konstitusi Nomor 27/PUU-IX/2011 serta peraturan perundang-undangan lain dan perundang-undangan dibawah undangundang yang memiliki keterkaitan dengan pengalihan pengalihan sebagian pekerjaan kepada perusahaan lain (outsourcing).

Metode pendekatan yang digunakan dalam penelitian ini adalah metode pendekatan perundang-undangan (statute approach), pendekatan historis atau sejarah (historical approach), dan pendekatan konseptual (conceptual approach). Bahanbahan hukum yang akan digunakan Penulis dalam penelitian ini antara lain bahan hukum primer, sekunder dan tersier.

${ }^{8}$ Mukti Fajar ND dan Yulianto Achmad, Dualisme Penelitian Hukum Normatif dan Empiris, Cet,. 2, Pustaka Pelajar, Yogyakarta, 2013, h. 34.
Bahan-bahan hukum primer merupakan bahan hukum yang bersifat autoritatif, artinya mempunyai otoritas. Bahan-bahan hukum primer terdiri dari perundang-undangan, catatan-catatan resmi atau risalah dalam pembuatan perundangundangan dan putusan-putusan hakim. ${ }^{9}$ Dalam penelitian ini Penulis menggunakan sumber bahan hukum primer perundangundangan dan peraturan lainnya dibawah undang-undang yang mempunyai keterkaitan dan relevansi dengan objek yang Penulis teliti.

Bahan-bahan hukum sekunder berupa semua publikasi tentang hukum yang bukan merupakan dokumen-dokumen resmi. Publikasi tentang hukum meliputi buku-buku teks, kamus-kamus hukum, jurnal-jurnal hukum dan komentar atas putusan pengadilan. ${ }^{10}$ Kegunaan bahan hukum sekunder adalah memberikan kepada Peneliti semacam petunjuk kearah mana peneliti melangkah. Apabila tulisan itu berupa tesis, desertasi ataupun artikelartikel dalam jurnal hukum dan boleh jadi tulisan tersebut memberikan inspirasi bagi peneliti untuk menjadi titik anjak dalam memulai penelitian. Buku-buku dan artikelartikel hukum yang dirujuk sudah tentu memiliki relevansi dengan apa yang dikehendaki peneliti. Begitupun atas komentar-komentar atas putusan pengadilan perlu diseleksi kasus-kasus dengan objek penelitian. Bisa saja buku maupun artikel mengenai masalah yang lain dari objek penelitian dijadikan rujukan asal memang ada keterkaitan dengan apa yang diteliti tersebut. ${ }^{11}$

Bahan hukum sekunder diperoleh Penulis dengan mencari dan

\footnotetext{
${ }^{9}$ Ibid., h. 181.

${ }^{10}$ Ibid.

${ }^{11}$ Ibid., h. 196.
} 
mengumpulkan buku-buku, kamus hukum, jurnal-jurnal, komentar para ahli serta karya ilmiah lainnya yang memiliki keterkaitan dan relevansi dengan objek penelitian.

Bahan hukum tersier juga merupakan bahan hukum yang dapat menjelaskan baik bahan hukum primer maupun bahan hukum sekunder, yang berupa kamus, ensiklopedi, leksikon dan lain-lain. ${ }^{12}$ Bahan hukum tersier dapat diperoleh Penulis melalui kamus besar bahasa Indonesia, ensiklopedia serta bukubuku maupun catatan non-hukum lainnya yang dapat dijadikan bahan pendukung dalam penelitian.

Teknik pengumpulan bahan hukum dilakukan dengan melakukan penelusuran bahan hukum terhadap isu yang akan diangkat.Bahan hukum yang sudah terkumpul, selanjutnya dianalisis dan dideskripsikan. Pengumpulan bahan hukum didasarkan pada keterkaitan serta keterpaduan informasi untuk memperoleh hasil penelitian yang lebih akurat. Teknik pengumpulan data dalam penelitian hukum normatif dilakukan dengan studi pustaka terhadap bahan-bahan hukum, baik bahan hukum primer, bahan hukum sekunder, maupun bahan hukum tersier dan atau bahan non hukum. Penelusuran bahanbahan hukum tersebut dapat dilakukan dengan membaca, melihat, mendengarkan, maupun sekarang banyak dilakukan penelusuran bahan hukum tersebut melalui media internet. ${ }^{13}$

\subsection{PEMBAHASAN}

\section{A. Pihak-Pihak Dalam Perjanjian Outsourcing}

Dalam outsourcing pihak-pihak terlibat dalam hubungan kerja tidak hanya melibatkan pengusaha dan pekerja, Op.Cit., h. 158. melainkan melibatkan tiga pihak yaitu perusahaan penerima pekerjaan, perusahaan pemberi pekerjaan dan pekerja/buruh.

a. Perusahaan Penerima Pekerjaan

Dalam melakukan oursourcing, perusahaan penerima pekerjaan disebut juga sebagai pemborong ataupun perusahaan penerima pemborongan pekerjaan. Dalam Pasal 1 angka 2 Keputusan Menteri Tenaga Kerja dan Transmigrasi

Nomor KEP.220/MEN/X/2004 yang dimaksud dengan Perusahaan Penerima Pemborongan Pekerjaan adalah perusahaan lain yang menerima penyerahan sebagian pelaksanaan pekerjaan dari perusahaan pemberi pekerjaan, sedangkan dalam Pasal 1 angka Keputusan Menteri Tenaga Kerja dan Transmigrasi Nomor KEP.101/MEN/VI/2004 yang dimaksud dengan Perusahaan Penyedia Jasa adalah perusahaan berbadan hukum yang dalam kegiatan usahanya menyediakan jasa pekerja/buruh untuk dipekerjakan di perusahaan pemberi pekerjaan.

b. Perusahaan Pemberi Pekerjaan

$$
\text { Dalam Pasal } 1 \text { angka }
$$

Keputusan Menteri Tenaga kerja dan Transmigrasi Nomor KEP.220/MEN/X/2004 disebutkan bahwa perusahaan yang selanjutnya disebut perusahaan pemberi pekerjaan adalah

1. setiap bentuk usaha yang berbadan hukum atau tidak, milik orang perseorangan, milik persekuatuan atau milik badan hukum, baik milik swasta maupun milik negara yang

${ }^{13}$ Ibid., h. 160. 
mempekerjakan pekerja/buruh dengan membayar upah atau imbalan dalam bentuk lain;

2. usaha-usaha sosial dan usahausaha lain yang mempunyai pengurus dan mempekerjakan orang lain dengan membayar upah atau imbalan dalam bentuk lain.

Pertimbangan yang dijadikan alasan perusahaan pengguna jasa untuk melakukan outsourcing ialah karena terdapat kesederhanaan bagi pengusaha tempat kerja dipekerjakan, yakni perusahaan mengurus permasalahan perekrutan dan pelatihan kerja. Mereka hanya menentukan kriteria tenaga kerja yang diperlukan dan memberikannya kepada perusahaan pemborong/outsourcing. Hal ini merupakan efisiensi bagi perusahaan untuk melakukan bisnis inti (core business).

c. Pekerja/Buruh

Pengertian pekerja/buruh dalam outsourcing sebenarnya tidak berbeda jauh dengan pengertian pekerja/buruh berdasarkan pengertian ketenagakerjaan. Dalam Keputusan Menteri Tenaga Kerja dan Transmigrasi Nomor KEP.220./MEN/X/2004. Pasal 1 angka 3 menyebutkan pengertian pekerja/buruh adalah setiap orang yang bekerja pada perusahaan penerima pemborongan pekerjaan dengan menerima upah atau imbalan dalam bentuk lain.

\section{B. Perlindungan dan Jaminan Hak Pekerja/Buruh Outsorcing Oleh Undang-Undang Nomor 13 Tahun 2003 Tentang Ketenagakerjaan}

Di dalam perlindungan hukum, minimal ada dua pihak, di mana perlindungan hukum difokuskan pada salah satu pihak, dengan tindakan-tindakannya, berhadapan dengan rakyat yang dikenai tindakan-tindakan pemerintah tersebut. Segala sarana, di antaranya peraturan perundang-undangan, yang memfasilitasi pengajuan keberatan-keberatan oleh rakyat sebelum keputusan pemerintah mendapat bentuk definitif, merupakan perlindungan hukum yang preventif. Penanganan perlindungan hukum bagi rakyat oleh pengadilan merupakan perlindungan hukum yang represif. Perlindungan hukum dalam hal ini mencakup perlindungan hukum preventif maupun perlindungan hukum yang represif. ${ }^{14}$

Perlindungan hukum pekerja outsourcing yaitu pihak pekerja/buruh yang dalam kedudukan lebih lemah dari pengusaha/perusahaan baik terhadap perusahaan outsourcing (perusahaan penerima pekerjaan) maupun dalam kaitan dengan perusahaan pemberi pekerjaan harus mendapat perlindungan hukum baik perlindungan hukum preventif maupun perlindungan hukum represif. Perlindungan hukum preventif dimaksudkan bahwa pekerja outsourcing dijamin kepastian dan perlindungan hukumnya terhadap hak-hak normatifnya seperti upah, kesejahteraan, syarat-syarat kerja, keselamatan dan kecelakaan kerja, jaminan sosial dan lainlain sesuai dengan undang-undang ketenagakerjaan yang berlaku. Sedangkan 
perlindungan hukum yang represif, akan dikaji/ditelaah tentang beberapa perselisihan hubungan industrial kasus putusan pengadilan yang berkenaan dengan kepastian hukum status hubungan kerja outsourcing.

Perlindungan hukum pekerja secara represif dapat meliputi perlindungan dalam perselisihan hubungan industrial dan perlindungan dalam Pemutusan Hubungan Kerja (PHK). ${ }^{15}$ Perselisihan antara pekerja/buruh dengan pengusaha (pemberi kerja) termasuk pekerja outsourcing dengan perusahaan pemborong pekerjaan atau perusahaan penyedia jasa pekerja (sebagai perusahaan penerima pekerjaan) dan perusahaan pemberi pekerjaan dalam hukum ketenagakerjaan merupakan perselisihan hubungan industrial.

Menurut Pasal 1 angka UndangUndang Nomor 2 Tahun 2004 tentang Penyelesaian Sengketa Hubungan Industrial, perselisihan hubungan industrial adalah perbedaan pendapat yang mengakibatkan pertentangan antara pengusaha atau gabungan pengusaha dengan pekerja/buruh atau serikat buruh karena adanya perselisihan mengenai hak, perselisihan kepentingan, perselisihan pemutusan hubungan kerja dan perselisihan antar serikat pekerja/serikat buruh hanya dalam satu perusahaan.

\section{Perlindungan hukum \\ pekerja/buruh putusan Makamah Konstitusi Nomor 27/PUU-IX/2011}

Pengaturan outsourcing atau penyerahan sebagian pelaksanaan pekerjaan kepada perusahaan lainnya menurut Hukum Ketenagakerjaan di Indonesia diatur dalam Pasal 64 UndangUndang Nomor 13 Tahun 2003 tentang
Ketenagakerjaan, "Perusahaan dapat menyerahkan sebagian pelaksanaan pekerjaan kepada perusahaan lainnya melalui perjanjian pemborongan pekerjaan atau penyediaan jasa pekerja/buruh yang dibuat secara tertulis" Berdasarkan ketentuan pasal di atas, outsourcing dapat dibagi menjadi dua bentuk perjanjian bisnis yakni:

a. Pemborongan Pekerjaan, yaitu pengalihan suatu pekerjaan kepada vendor outsourcing. Vendor bertanggung jawab sepenuhnya terhadap pekerjaan yang dialihkan beserta hal-hal yang bersifat teknis (pengaturan operasional) maupun hal-hal yang bersifat nonteknis (administrasi kepegawaian). Pekerjaan yang dialihkan adalah pekerjaan yang bisa diukur volumenya, dan fee yang dikenakan oleh vendor adalah rupiah per satuan kerja $(\mathrm{Rp} / \mathrm{m} 2$, $\mathrm{Rp} / \mathrm{kg}, \quad$ dsb.). Contoh: pemborongan pekerjaan cleaning service, jasa pembasmian hama, jasa katering, dan sebagainya.

b. Penyediaan Jasa Pekerja atau Buruh yaitu pengalihan suatu posisi kepada vendor outsourcing. Vendor tersebut menempatkan karyawannya untuk mengisi posisi tersebut. Vendor hanya bertanggung jawab terhadap manajemen karyawan tersebut serta halhal yang bersifat nonsteknis lainnya, sedangkan halhal teknis menjadi tanggung jawab perusahaan selaku pengguna dari karyawan vendor. Sesuai dengan 148.

15 I Nyoman Putu Budiartha, Op.Cit., h. 
pengertian diatas berarti yang dimaksud dengan perjanjian outsourching merupakan perjanjian bisnis antara satu perusahaan (dapat juga orang perorangan) dengan perusahaan lain (harus berbadan hukum) untuk suatu kesepakatan bersama mengenai penyerahan sebagian pelaksanaan pekerjaan. Jadi, yang dimaksud dengan pekerja outsourcing adalah pekerja yang bekerja pada suatu perusahaan penyedia jasa pekerja atau perusahaan penerima pemborongan pekerjaan. Menurut ketentuan diatas sebenarnya pekerja yang bekerja pada perusahaan outsourcing telah sangat diproteksi oleh aturan. Namun, dalam tataran pelaksanaan dilapangan banyak aturan-aturan yang dilanggar maupun terpaksa dilanggar sehingga pada 17 Januari 2012 lalu, Mahkamah Konstitusi dengan putusan Nomor 27/PUUIX/2011 mengabulkan permohonan pengujian UndangUndang Nomor 13 tahun 2003 tentang Ketenagakerjaan yang diajukan oleh Ketua Umum Aliansi Petugas Pembaca Meteran Listrik (AP2ML).

Dalam pertimbangan hukum Mahkamah Konstitusi pada putusan Makamah Konstitusi Nomor 27/PUUIX/2011, menegaskan outsourcing adalah kebijakan usaha yang wajar dari suatu perusahaan dalam rangka efisiensi usaha. Akan tetapi, pekerja/buruh yang melaksanakan pekerjaan dalam perusahaan outsourcing tidak boleh kehilangan hakhaknya yang dilindungi konstitusi. Agar para pekerja/buruh tidak dieksploitasi,
Mahkamah Konstitusi menawarkan dua model penggunaan outsourcing, yakni:

1. Mensyaratkan agar perjanjian kerja antara pekerja/buruh dan perusahaan yang melaksanakan pekerjaan outsourcing tidak berbentuk Perjanjian Kerja Waktu Tertentu (PKWT), tetapi berbentuk Perjanjian Kerja Waktu Tidak Tertentu (PKWTT); dan

2. Apabila hubungan kerja antara pekerja/buruh dengan perusahaan yang melakukan pekerjaan outsourcing berdasarkan Perjanjian Kerja Waktu Tertentu (PKWT) maka pekerja/buruh harus tetap mendapat perlindungan atas hakhaknya sebagai pekerja/buruh dengan menerapkan prinsip pengalihan tindakan perlindungan bagi pekerja/buruh (Transfer of Undertaking Protection of Employment atau TUPE) yang bekerja pada perusahaan yang melaksanakan pekerjaan outsourcing.

$\begin{array}{ll}\begin{array}{l}\text { Dengan } \\ \text { pengalihan }\end{array} & \begin{array}{l}\text { menerapkan } \\ \text { perlindungan, }\end{array} \\ \text { ketika }\end{array}$ perusahaan pemberi kerja tidak lagi memberikan pekerjaan borongan atau penyediaan jasa pekerja/buruh kepada suatu perusahaan outsourcing yang lama dan memberikan pekerjaan tersebut kepada perusahaan outsourcing yang baru, maka selama pekerjaan yang diperintahkan untuk dikerjakan masih ada dan berlanjut, perusahaan penyedia jasa baru tersebut harus melanjutkan kontrak kerja yang telah ada sebelumnya, tanpa mengubah ketentuan yang ada dalam kontrak, tanpa persetujuan pihak-pihak yang berkepentingan, kecuali perubahan untuk 
meningkatkan keuntungan bagi pekerja/buruh karena bertambahnya pengalaman dan masa kerjanya.

Aturan tersebut tidak saja memberikan kepastian akan keberlanjutan pekerjaan para pekerja/buruh outsourcing, tetapi juga memberikan perlindungan terhadap aspek-aspek kesejahteraan lainnya, karena dalam aturan tersebut para pekerja outsourcing tidak diperlakukan sebagai pekerja baru. Masa kerja yang telah dilalui para pekerja/buruh outsourcing tersebut tetap dianggap ada dan diperhitungkan, sehingga pekerja/buruh outsourcing dapat menikmati hak-hak sebagai pekerja secara layak dan proporsional. Dengan adanya pilihan model demikian, perlindungan hak kepada pekerja/buruh outsourcing lebih menjanjikan

Pasca putusan Makamah Konstitusi Nomor 27/PUU-IX/2011, pemerintah mengeluarkan Peraturan Menteri Tenaga Kerja dan Transmigrasi Nomor 19 Tahun 2012 Tentang Syarat-Syarat Penyerahan Sebagian Pelaksanaan Pekerjaan Kepada Perusahaan Lain yang mencabut Keputusan Menteri Tenaga Kerja dan Transmigrasi Nomor KEP.101/MEN/VI/2004 tentang Tata Cara Perijinan Perusahaan Penyedia Jasa Pekerja/Buruh dan Keputusan Menteri Tenaga Kerja dan Transmigrasi Nomor KEP.220/MEN/X/2004 tentang SyaratSyarat Penyerahan Sebagian Pelaksanaan Pekerjaan Kepada Perusahaan Lain.

Secara umum tujuan pembangunan ketenagakerjaan tercantum dalam Pasal 4 Undang-Undang Nomor 13 Tahun 2003 tentang Ketenagakerjaan yaitu:

a. memberdayakan dan mendayagunakan tenaga kerja secara optimal dan manusiawi;

b. mewujudkan pemerataan kesempatan kerja dan penyediaan tenaga kerja yang sesuai dengan kebutuhan pembangunan nasional dan daerah;

c. memberikan perlindungan kepada tenaga kerja dalam mewujudkan kesejahteraan; dan

d. meningkatkan kesejahteraan tenaga kerja dan keluarganya.

Dengan adanya putusan Makamah Konstitusi Nomor 27/PUU-IX/2011 yang menganulir frasa "perjanjian kerja waktu tertentu" dalam Pasal 65 ayat (7) dan frasa "...perjanjian kerja untuk waktu tertentu" dalam Pasal 66 ayat (2) huruf b UndangUndang Nomor 13 Tahun 2003 tentang Ketenagakerjaan, bertentangan dengan UUD 1945 sepanjang dalam perjanjian kerja tersebut tidak disyaratkan adanya pengalihan perlindungan hak-hak bagi pekerja/buruh yang objek kerjanya tetap ada, walaupun terjadi pergantian perusahaan yang melaksanakan sebagian pekerjaan borongan dari perusahaan lain atau perusahaan penyedia jasa pekerja/buruh. Putusan tersebut semakin menjamin perlindungan pekerja/buruh outsourcing dari segi konstitusional.

Demikian halnya dengan Peraturan Menteri Tenaga Kerja dan Transmigrasi Nomor 19 Tahun 2012 Tentang SyaratSyarat Penyerahan Sebagian Pelaksanaan Pekerjaan Kepada Perusahaan Lain. Dalam peraturan tersebut model penyerahan sebagian pelaksanaan pekerjaan kepada perusahaan lain dapat dibagi menjadi 2 (dua) yakni dilakukan melalui perjanjian pemborongan pekerjaan atau perjanjian penyediaan jasa pekerja/buruh.

Dalam ketentuan tersebut, pekerjaan yang dapat diserahkan kepada perusahaan penerima pemborongan harus memenuhi syarat sebagai berikut: 
a. Dilakukan secara terpisah dari kegiatan utama baik manajemen maupun kegiatan pelaksanaan pekerjaan;

b. Dilakukan dengan perintah langsung atau tidak langsung dari pemberi pekerjaan, dimaksudkan untuk memberi penjelasan tentang cara melaksanakan pekerjaan agar sesuai dengan standar yang ditetapkan oleh perusahaan pemberi pekerjaan;

c. Merupakan kegiatan penunjang perusahaan secara keseluruhan, artinya kegiatan tersebut merupakan kegiatan yang mendukung dan memperlancar pelaksanaan kegiatan utama sesuai dengan alur kegiatan proses pelaksanaan pekerjaan yang ditetapkan oleh asosiasi sektor usaha yang dibentuk sesuai peraturan perundangundangan; dan

d. Tidak menghambat proses produksi secara langsung, artinya kegiatan tersebut merupakan kegiatan tambahan yang apabila tidak dilakukan oleh perusahaan pemberi pekerjaan, proses pelaksanaan pekerjaan tetap berjalan sebagaimana mestinya.

Berdasarkan Pasal 5 Peraturan Menteri Tenaga Kerja dan Transmigrasi Nomor 19 Tahun 2012 Tentang SyaratSyarat Penyerahan Sebagian Pelaksanaan Pekerjaan Kepada Perusahaan Lain, jenis pekerjaan penunjang yang akan diserahkan kepada perusahaan penerima pemborongan harus dilaporkan oleh perusahaan pemberi pekerjaan kepada instansi yang bertanggung jawab di bidang ketenagakerjaan kabupaten/kota tempat pemborongan pekerjaan dilaksanakan.

Sedangkan dalam peraturan tersebut, pekerjaan yang dapat diserahkan kepada perusahaan penyedia jasa pekerja/buruh merupakan kegiatan jasa penunjang atau yang tidak berhubungan langsung dengan proses produksi meliputi:

a. Usaha pelayanan kebersihan (cleaning service);

b. Usaha penyediaan makanan bagi pekerja/buruh (catering);

c. Usaha tenaga pengaman (security/satuan pengamanan);

d. Usaha jasa penunjang di pertambangan dan perminyakan; dan

e. Usaha penyediaan angkutan bagi pekerja/buruh.

Dalam ketentuan Pasal 28 Peraturan Menteri Tenaga Kerja dan Transmigrasi Nomor 19 Tahun 2012 Tentang SyaratSyarat Penyerahan Sebagian Pelaksanaan Pekerjaan Kepada Perusahaan Lain, bahwa setiap perjanjian kerja penyediaan jasa pekerja/buruh wajib memuat ketentuan yang menjamin terpenuhinya hak-hak pekerja/buruh dalam hubungan kerja sebagaimana diatur dalam peraturan perundang-undangan. Hal ini dipertegas dalam Pasal 29 ayat (2) yang apabila hubungan kerja didasarkan atas perjanjian kerja waktu tertentu yang objek kerjanya tetap ada sekurang-kurangnya harus memuat:

a. jaminan kelangsungan bekerja;

b. jaminan terpenuhinya hak-hak pekerja/buruh sesuai dengan peraturan perundang-undangan dan yang diperjanjikan; dan 
c. jaminan perhitungan masa kerja apabila terjadi pergantian perusahaan penyedia jasa pekerja/buruh untuk menetapkan upah.

Terwujudnya tujuan pembangunan ketenagakerjaan sangat dipengaruhi oleh konsisten atau tidaknya beberapa unsur dalam penerapan dan penegakan hukum. Konsistensi penegakan hukum tersebut terhadap nilai-nilai moral, hukum dan kesadaran hukum bagi pekerja/buruh, pengusaha maupun lembaga negara yang membidangi ketenagakerjaan. Menurut Soerjono Soekanto, faktor-faktor sebagai masalah pokok yang mempengaruhi penegakan hukum adalah: ${ }^{16}$

1. Faktor hukum sendiri (undangundang);

2. Faktor penegak hukum, yakni pihak-pihak yang membentuk dan menerapkan hukum;

3. Faktor sarana atau fasilitas yang mendukung penegakan hukum;

4. Faktor masyarakat, yakni lingkungan di mana hukum tersebut berlaku atau diterapkan; dan

5. Faktor kebudayaan, yakni sebagai hasil karya cipta dan rasa yang didasarkan pada karsa manusia di dalam pergaulan hidup lembaga penerapan hukum.

Secara konstitusional, aturan-aturan yang mengatur tentang penggunaan pekerja/buruh outsourcing telah memberikan perlindungan terhadap hakhak pekerja/buruh outsourcing tersebut. Namun penerapan yang tidak sesuai ketentuan perundang-undangan membuat keadaan pekerja/buruh berada pada posisi

${ }^{16}$ Soerjono Soekanto, Faktor-Faktor Yang Mempengaruhi Penegakan Hukum, Cet. 4, PT Rajagrafindo Persada, Jakarta, 2002, h. 5. yang sangat dirugikan. Untuk mewujudkan tujuan pembangunan ketenagakerjaan yang mewujudkan masyarakat sejahtera, adil, makmur, dan merata serta terpenuhi hakhak dan perlindungan yang mendasar bagi tenaga kerja dan pekerja/buruh serta pada saat yang bersamaan dapat mewujudkan kondisi yang kondusif bagi pengembangan dunia usaha perlu adanya komitmen dan konsistensi untuk menjalankan serta mengawasi berjalannya aturan perundangundangan.

\subsection{KESIMPULAN}

Bentuk perlindungan hukum pekerja/buruh outsourcing dalam UndangUndang Nomor 13 Tahun 2003 Tentang Ketenagakerjaan dilakukan dalam bentuk preventif berupa pencegahan dan represif berupa penuntutan hak kepada lembaga penyelesaian perselisihan hubungan industrial. Perlindungan preventif merupakan upaya pencegahan dengan dasar hukum yang diatur dalam Pasal 65 dan Pasal 66 Undang-Undang Nomor 13 Tahun 2003 Tentang Ketenagakerjaan serta peraturan pelaksanaan berupa Keputusan Menteri Tenaga Kerja dan Transmigrasi Nomor KEP.220/MEN/X/2004 Tentang Syarat-Syarat Penyerahan Sebagian Pelaksanaan Pekerjaan Kepada Perusahaan Lain dan Keputusan Menteri Tenaga Kerja dan Transmigrasi Nomor KEP.101/MEN/VI/2004 Tentang Tata Cara Perizinan Perusahaan Penyedia Jasa Pekerja/Buruh. Perlindungan represif merupakan penekanan saat terjadi perselisihan baik itu perselisihan hak maupun saat terjadi pemutusan hubungan kerja.. Penyelelesaian perselisihan diatur dalam Undang-Undang Nomor 2 Tahun 
2004 tentang Penyelesaian Sengketa Hubungan Industrial.

Dengan adanya putusan Makamah Konstitusi Nomor 27/PUU-IX/2011 yang menganulir frasa "perjanjian kerja waktu tertentu" dalam Pasal 65 ayat (7) dan frasa "...perjanjian kerja untuk waktu tertentu" dalam Pasal 66 ayat (2) huruf b UndangUndang Nomor 13 Tahun 2003 tentang Ketenagakerjaan, bertentangan dengan UUD 1945 sepanjang dalam perjanjian kerja tersebut tidak disyaratkan adanya pengalihan perlindungan hak-hak bagi pekerja/buruh yang objek kerjanya tetap ada, walaupun terjadi pergantian perusahaan yang melaksanakan sebagian pekerjaan borongan dari perusahaan lain atau perusahaan penyedia jasa pekerja/buruh. Putusan tersebut semakin menjamin perlindungan pekerja/buruh outsourcing dari segi konstitusional. Hal tersebut diperkuan dengan dikeluarkannya Peraturan Menteri Tenaga Kerja dan Transmigrasi Nomor 19 tahun 2012 Tentang Syarat-Syarat Penyerahan Sebagian Pelaksanaan Pekerjaan Kepada Perusahaan Lain.

Saran yang dapat dipergunakan dalam penelitian adalah Undang-Undang Nomor 13 Tahun 2003 tentang Ketenagakerjaan sudah saatnya dilakukan revisi atau perubahan dengan menyesuaikan perkembangan zaman. Namun dalam menyesuaikan perubahan tersebut selayaknya mengedepankan perlindungan hak-hak dasar pekerja/buruh, terutama pada model perjanjian kerja outsourcing.

Pasca adanya putusan Makamah Konstitusi Nomor 27/PUU-IX/2011 yang semakin memberikan perlindungan hakhak pekerja/buruh outsourcing secara konstitusional. Namun apabila dalam pelaksanaannya tidak dilakukan pengawasan maka hal tersebut akan sia-sia. Pegawai pengawas pada instansi yang membidangi ketenagakerjan harus peka terhadap bentuk perjanjian kerja outsourcing yang sangat berpotensi merugikan pekerja/buruh apabila pelaksanaannya tidak sesuai dengan perundang-undangan. Selain itu pegawai pengawas yang berada pada tingkat provinsi agar lebih maksimal dapat di pindah pada tingkat kabupaten/kota dan bekerjasama dengan serikat pekerja/serikat buruh dalam pengawasan guna menjamin pelaksanaan ketentuan yang sebagaimana mestinya.

\section{DAFTAR PUSTAKA}

Budiartha, I Nyoman Putu, Hukum Outsourcing Konsep Alih Daya, Bentuk Perlindungan dan Kepastian Hukum, Setara Press, Malang, 2016.

Budiono, Abdul Rachmad, Hukum Perburuhan, PT Indeks, Jakarta, 2009.

Damanik, Sehat, Outsourcing dan Perjanjian Kerja Menurut UU No. 13 Tahun 2003 tentang Ketenagakerjaan Sebagai Penuntun Untuk Merencanakan, Melaksanakan Bisnis Outsourcing dan Perjanjian Kerja, DSS Publishing, Jakarta, 2006.

Fahrojih, Ikhwan, Hukum Perburuhan, Setara Press, Malang, 2016.

Hadjon, Philipus M., Perlindungan Hukum Bagi Rakyat Indonesia, Edisi Khusus, Percetakan M2 Print, Surabaya, 2007.

Herawati, Rina, Kontrak dan Outsourcing Harus Makin Diwaspadai, Yayasan AKATIGA, Bandung, 2010.

Husni, Lalu, Pengantar Hukum Ketenagakerjaan, Cet. 14, Edisi Revisi, Rajawali Pers, Jakarta, 2016. 
Husni, Lalu, Hukum Ketenagakerjaan Indonesia, Raja Grafindo Persada, Jakarta, 2008.

Indrajit, Richardus Eko dan Richardus Djokopranoto, Proses Bisnis Outsourcing, PT. Gramedia Widiasarana Indonesia, Jakarta, 2003

Jehani, Libertus, Hak-hak Karyawan Kontrak, Praminta Offset, Jakarta, 2008.

Khakim, Abdul, Dasar-Dasar Hukum Ketenagakerjaan, Cet. 1, Edisi IV, Citra Aditya Bakti, Bandung, 2014.

Khakim, Abdul, Aspek Hukum Perjanjian Kerja, Peraturan Perusahaan, Dan Perjanjian Kerja Bersama $(P K B)$, Cet. 1, PT Citra Aditya Bakti, Bandung, 2017.

Kusumo, Bambang S Widagdo, Mengurai Benang Kusut Hukum Perburuhan, CV Annadia, Sidoarjo, 2006.

Marzuki, Peter Mahmud, Penelitian hukum, Cet. 12, Edisi Revisi, Prenada Media Group, Jakarta, 2016.

Pakpahan, Mochtar dan Ruth Damaihati Pakpahan, Konflik Kepentingan Outsourcing dan Kontrak dalam Undang-Undang Nomor 13 Tahun 2003, PT. Bumi Intitama Sejahtera, Jakarta, 2010.

Penggabean, H.P., Hukum Acara Penyelesaian Perselisihan Hubungan Industrial, Jala Permata, Jakarta, 2007.

Priambada, Komang \& Agus Eka Maharta, Outsourcing Versus Serikat Pekerja?, Alihdaya Publishing, Jakarta, 2008.

Simanjuntak, Payaman J., Manajemen Hubungan Industrial, Jala Permata Aksara, Jakarta, 2009.

Soekanto, Soerjono, Faktor-Faktor Yang Mempengaruhi Penegakan Hukum, Cet. 4, PT Rajagrafindo Persada, Jakarta, 2002.
Soepomo, Iman, Pengantar Hukum Perburuhan, Cet. 11, Djambatan, Jakarta, 1995.

Sutedi, Adrian, Hukum Perburuhan, Jakarta, Sinar Grafika, 2009.

Suwondo, Chandra, Outsourcing, Implementasi di Indonesia, Praminta Offset, Jakarta, 2008.

Tunggal, Amin Widjaja, Outsourcing Konsep dan Kasus, HARVINDO, Jakarta, 2008.

Wijayanti, Asri, Hukum Ketenagakerjaan Pasca Reformasi, Cet. 7, Sinar Grafika, Jakarta, 2017.

\section{Perundang-Undangan}

Undang-Undang Dasar Negara Republik Indonesia Tahun 1945.

Kitab Undang-Undang Hukum Perdata.

Undang-Undang Nomor 13 Tahun 2003 tentang Ketenagakerjaan.

Undang-Undang Nomor 24 Tahun 2003 Tentang Mahkamah Konstitusi.

Undang-Undang Nomor 2 Tahun 2004 Tentang Penyelesaian Perselisihan Hubungan Industrial.

Putusan Mahkamah Konstitusi Republik Indonesia Nomor 27/PPUIX/2011 Tanggal 17 Januari 2011.

Keputusan Menteri Tenaga Kerja Nomor KEP.220/MEN/X/2004 Tentang SyaratSyarat Penyerahan Sebagian Pelaksanaan Pekerjaan Kepada Perusahaan Lain.

Keputusan Menteri Tenaga Kerja dan Transmigrasi Nomor KEP.101/MEN/VI/2004 Tentang Tata Cara Perizinan Perusahaan Penyedia Jasa Pekerja/Buruh.

Peraturan Menteri Tenaga Kerja dan Transmigrasi Nomor 19 tahun 2012 Tentang Syarat-Syarat Penyerahan Sebagian Pelaksanaan Pekerjaan Kepada Perusahaan Lain. 